\title{
The Everyday (in) Urbanism: What's New on the Spot
}

\section{Luca Lazzarinia}

\begin{abstract}
The paper aims at measuring the influence that the everyday theme has exercised in the formation of the idea of space that is permeating the thought of many contemporary urban planners. Through the investigation of two recent approaches, the Italian and the American ones, the complex relationships between daily practices and urban spaces, in the continuous redefinition of the concepts of public and private sphere, are described. In this context, the Everyday Urbanists' work had the merit to reveal and investigate the social possibilities offered by the patterns of everyday life. They were among the first to speak about a citizenship redefinition, process which has been increasingly debated by many scholars. Citizenship is thus turning to be less formal, while becoming more substantive and insurgent. The paper demonstrates that, according to this crucial change, new and meaningful relations between citizenship and planning can be established and that these are able to open planning practice up to the present ethnographical possibilities of the urban space, and to its tactical and polysemic dimensions.
\end{abstract}

Keywords

Everyday, Everyday Urbanism, citizenship, urban project

The recent changes affecting the structure and the meaning of public spaces are giving rise to a deeper transformation in the city. Within the public realm of the city, the not fully controllable forms of appropriation by the new populations are challenging the pre-established orders of the society. These silent and often subtle practices offer the chance to reflect again on the theme of everyday in urbanism. This appears to be relevant also with respect to the growing attention by scholars to disclose and describe the hidden practices connoting the public spaces, especially those which are defined as marginal and vacant.

This work does not aim to study the "everyday" in order to rebuild another genealogy of the "daily life", but to understand how and if this issue has influenced the current ways of doing planning in Italy and abroad. Although the everyday theme has widely permeated the western thinking of the second half of the twentieth century and it was largely studied by urban studies over the last twenty years, the rich literature about the everyday was not supported by a clear investigation of the influence that this theme had on urbanism, especially in the Italian context.

To this regard, the paper wants to show how a theoretical substrate of the post-modern urbanism, referring to the everyday theme, moves in continuity to the thoughts of Michel De Certeau and Henry Lefebvre. The two intellectuals represent two of the most influential profiles of the post-war period that

\section{aPolitecnico di Torino, Italy}

\section{Correspondent Author:}

Luca Lazzarini, via Accademia Albertina 27, 10123, Torino TO, Italy 
placed the sphere of everyday at the center of their research path. Moreover, this work would like to clarify the degree of influence that the theme of the everyday life has exercised with respect to the formation of the idea of space that permeates the thinking of many contemporary urban planners. It also intends to demonstrate that the formation of such thinking is interwoven to the increasing complexity of the idea of citizenship, according to a mutual process of deconstruction and reconstruction, which has profoundly altered its profile.

This work is divided into seven parts. The first paragraph critically retraces the thinking of Henry Lefebvre and Michel De Certeau in order to make explicit their contributions to the construction of a new research orientation that, from the sixties on, critically read and investigated the urban reality. In the second paragraph, the author tries to clarify the debt that some Italian planners' positions have with respect to the new critical orientation affirmed by the two intellectuals. Many planners in Italy, since the early nineties, started to read, speak, and write about the "everyday", contributing to affirming a new way of interpreting and designing the urban spaces. In the third paragraph, the author looks at the American context of the "Everyday Urbanism" approach that was born and developed in the USA in the late nineties. The Everyday Urbanism has affirmed a new attention to everyday politics in the design of urban spaces. In the fourth paragraph, Henri Lefebvre's thought is again explored in order to demonstrate his significant contribution in building "a critique of everyday life" in urbanism. The goal is to demonstrate how the direct correlation between "space and differences" in relationship to the urban has produced a significant step forward in the contemporary concept of public space. In the fifth paragraph, the author investigates the terms in which according to some scholars, it is looming a redefinition of the concept of citizenship as a result of the new practices of appropriation of public spaces by the new populations.
The author explores the positions of two contemporary intellectuals, James Holston and Etienne Balibar, whose works have helped to broaden the debate towards a need to recognize new and different forms of acquisition of rights, not necessarily related to formal status. The work ends with a clarification of the relationship between citizenship and planning and with a reflection on the importance that this theme has in urban planning and in the ways we think about urban transformations.

\section{EVERYDAY GLANCES AND TRAJECTORIES}

During the twentieth century, the reflection on the everyday has gradually shifted from a tentative to legitimizing its theoretical framework to the attempt to give a measure to the continuous oscillation between "ordinary" and "extraordinary". In fact, it is around these two polarities that the study of everyday life was traditionally built, according to a predominant track oriented to emphasize its opposition to the dimension of exceptionality (Di Cori and Pontecorvo 2007).

Although the everyday theme shows a continual rejection to be enclosed within rigid disciplinary boundaries, and although it resists to any attempt to acquire a definitive shape within a framework of identitarian certainty (Di Cori and Pontecorvo 2007), it was one of the most fertile land on which modern thought has been subjected to criticism (Lefebvre 1958; De Certeau 1980; Foucault 1984). The everyday was also one of the most challenging research fields of reality that was able to free the knowledge from the claim to explain the deeper mechanisms of the intellect (Lefebvre 1958).

But in which ways has the everyday life permeated the intellectual thinking of the twentieth century? And, most importantly, in which terms has everyday life helped to establish a new view on urban reality?

Henri Lefebvre wrote that: "Human facts escape us. We go to find the human too far, or too deeply, in the clouds or in the mysteries, while it is waiting for 
us and surrounding us everywhere" (Lefebvre 1958). The problem of knowledge according to Lefebvre is a problem of glance. The true thought does not reside in some intellectual construction or in some profound essence of the soul. According to Lefebvre, the real knowledge surrounds us, and the only way to capture it, is to observe it, to open our eyes, and to catch it with our eyes. In this context, the relationship between prestigious facts and the set of daily events represents the crucial passage from appearance to reality. The deeper reality is manifested, therefore, in that series of objects, situations that we define are familiar, but also banal and inauthentic. "How, then, can't we be tempted to turn them away?" (Lefebvre 1958).

The Lefebvre's critique of everyday life appears to be a manifesto of a new way of observing reality. Thus, it is a program of intentions to reaffirm the concrete manifestation of the meanings and values in determining our lives and in directing our intellect. His reflection is oriented to reaffirm the critical thinking and it indeed becomes "a critic of men and of their actions" (Lefebvre 1958). In Lefebvre, the intellectual moves away from everyday life because it appears unbearable to him. "The neurosis of the nascent state" allows the intellectual to replace the banal everyday with emotions and illusions that are more attractive to him: the mysterious, the strange, and the bizarre describe a dimension of extraordinary that the man seeks in order to escape from the monotony of a life that is still waiting "to be transformed and founded on a new basis".

After about twenty years since the Lefebvre's first edition of the Critique of Everyday Life (1958), Michel De Certeau develops a different declination of the everyday. His view of reality is focused on the different shades of the human beings' practices, a glance that invites to look at what men do. De Certeau points out that the performances of human beings are declined in continuous productions, in hidden and often subtle poetics of actions, hardly able to transform the condition of men. The everyday life in De Certeau refers to the spatial dimension of the places. This is expressed by a "from below" perception of the city, according to a look that only the passerby can perceive. In the "urban trajectories" mentioned by De Certeau, the bodies of passers obey to a pattern of full and empty spaces, a urban "text" that they unknowingly write without being able to read (De Certeau 1980). In this context, the act of walking describes a poetic which is firstly and foremost textual as it leaves an imprint that manifests itself in words, acquiring a certain degree of readability. Therefore, the daily change in the physical space through the trajectory design assumes the value of writing a urban score. It is an ongoing process of physical movements of the body, some of which are opaque and blind with respect to the inhabited cities (De Certeau 1980). The everyday theme in De Certeau is not only an "art of making", a design of the human actions expressing a certain way of living in the world, but it is also a real "theory of everyday practices". Thus, it can be interpreted as a construction of a theoretical arsenal able to restore aurban history different from the one established by the modernist thought. Within his theory, the importance of the "trace" emerges and stands out as a real pedestrian enunciation. The walk in De Certeau makes possible a look from below on the material reality of the objects (Merlini 2001). The "trace" builds a temporal view of what has been (past) with respect to what is (present). The strong or subtle trajectories, simple lines on a city plan, refer to the essence of what has been, that is the act of passing through. The transcription of urban trajectories in the bi-dimensional representation of the plan, even though it is able to reconstruct a certain distance to the present, as it is a product of a look that denotes a set of space-time conditions typical of the past, becomes at the same time a "relic", as it arises in the temporal dimension of a projection surface (De Certeau 1980).

\section{CITY, DESCRIPTION, AND PROJECT}

The reflection on cities in the twentieth century is 
characterized by a specific ability to observe and describe, where the description is already "thought and project" (Secchi 1984).

In this sense, the emerging attention to the everyday, the ordinary, and the specific has allowed planning to recover ancient looks and techniques of observation (Secchi 2000). Bernardo Secchi wrote that: "The attention to the everyday connotes the whole 20th century" (Secchi 2005). In fact, the everyday is

Within the thoughts of architects and planners in the first decade of the socialist revolution in the Soviet Union, it is at the heart of the Frank Lloyd Wright's reflection, (...) it is at the center of the Situationists claims that, from the Fifties up to the Seventies, proposed a strategy of observation of everyday places profoundly different from the ones of the previous decades. (Secchi 2005)

In Italy, it is only since the early nineties that planners and urban scholars have begun to employ new techniques of narration and description using the everyday as a new theme of research and experimentation on the contemporary city. From now, city's description becomes a crucial operation in studying the relationships between cities' physical aspects and life plans of those who inhabit the urban space. In this sense, the centrality of the description in urban studies, beyond producing some relevant research experiences devoted to emphasizing the physical and material dimension of the city (among the many: Boeri, Lanzani, and Marini 1993; Basilico and Boeri 1998; Infussi and Merlini 1998), was able to claim a new design practice. This has developed in opposition to the modernist vision of the project that had expropriated the city from the presence of the human body (Secchi 2000).

The neo-phenomenological position, as it was identified by Cristina Bianchetti (Bianchetti 2003), is one of the more easily recognizable interpretative families in the urban studies of the nineties. It was the one that more than others has helped to establish a new descriptive practice of the urban dispersion (città diffusa). Accordingly, it is quite clear that how the landscape of urban sprawl has been the frame of the everyday. Low density settlements have represented that form of the city hosting the most individualized part of the society, locked inside the ideology of roots and identity, was jealous of the "private", of the intimacy and familiarity of the everyday (Secchi 2013), of le souci de soi $i^{2}$ (Foucault 1984). This individual's emergence explains "the new attention to the daily, bodily dimensions, to the physical well being and to the small stories" (Bianchetti 2015). The métropole des individuals mentioned by Bourdin (2005) is the place where the individual, affirming his/her particular form of experience of the world, is transposed in the clearest way (Bianchetti 2015).

These studies, while emphasizing the meticulous observation of the spaces in relation to social types, have profoundly changed the traditional analysis of the urban morphologies (Mareggi 2014). They have built a close reading of the geographies resulting from the combination of spaces and new lifestyles (see: Boeri et al. 1993; Munarin and Tosi 2001). The neo-phenomenological approach is indeed the research path that more than others was able to look at the city without being eyes-oriented, rejecting laws, value judgments, prejudices, or abstract entities that could influence the description. Bernardo Secchi in this sense has used the expression "descriptive anxiety" (Secchi 1995), which applies to the description of the society, even before interweaving a narrative about city's physical environment. In this sense, the description can never be neutral and objective: It always implies the observation of the contextual characters, the evaluation of its resources and its problems, and the formulation of modification hypothesis (Merlini 2001).

The urban project is the field in which the description has been tested, the ground where descriptive actions have built a different relationship to narrate the urban environment. The urban project has assumed the value of grouping different narratives 
of the city: "from below", "from above", and "over time" descriptions (Merlini 2001; Mareggi 2011). The neo-phenomenological approach, even if in same cases made the spatial classification prevailing on the argumentative energy (Bianchetti 2003), has had the merit of bringing attention to those urban materials that the urban research had long ignored, those everyday objects that permeate the lives of individuals, determining the quality levels and the livability of a given urban space. In this case, the theme of the fragment and of the decomposition into elementary units of the city (Viganò 2000), according to a "minimal rationality" (Secchi 1984), appears to be relevant, not only in relation to the scale of the description but also for being critical toward every comprehensive look, unable to perceive the true human dimension of architecture and cities. Through its oblique glance, the neo-phenomenological point of view has been able to see and describe the ordinary urban materials that have built, and continue to build incrementally, an everyday urban landscape, those objects which have become relevant with respect to the ways of designing the city (Merlini 2009).

\section{THE NEW SOCIAL POSSIBILITIES OF THE EVERYDAY SPACE}

We have just described how in Italy the everyday theoretical background has been able to originate a research debate in urbanism that, although characterized by some common recognizable characters (the attention to urban materials as the basic units of urban project, the emphasis on critical description of cities and territories, the capacity to read the city "from below", "from above", and "over time", etc.), has not given rise to a unique research path but rather to a nebula of reflections, research paths, and projects, each characterized by its own specific contents and themes.

Perhaps it is in the American context that the reflection on the everyday has given origin to a more solid frame, a definite perimeter of design approach named, albeit in a reductive and simplifying way, "Everyday Urbanism". Free from the wish to draw a profile of this research and design approach ${ }^{3}$, the intention here is rather to critically delineate its contribution to the narrative of new social possibilities connoting the complexity of urban space and to the attention to the micro-politics processes taking place in the city's marginality.

In this sense, the Everyday Urbanism was not only capable of (re)affirming the primacy of human experience as the key aspect of any definition of "urbanism" (Wirth 1938), but it also allowed to "represent a social transition zone and potential possibilities of new social structures and forms of imagination" (Chase, Crawford, and Kalisky 1999). Everyday Urbanists recognize in the positions of Henry Lefebvre, Guy Debord, and Michel De Certeau, a clear introduction to the rich deposit of urban meanings of the city. Their, albeit different, identification of the concept of everyday life forms a sort of theoretical background of the Everyday Urbanism. As Lefebvre, Debord, and De Certeau, Everyday Urbanists intend "urbanism to be a human and social discourse" (Chase et al. 1999).

Already defined "nonutopian, conversational and nonstructuralist"4 (Kelbaugh 2001), Everyday Urbanism identifies the experience as more important than the physical form in defining the city. Following their approach, the city must be understood as "social product, created out of the demands of everyday use and the social struggles of urban inhabitants" (Chase et al. 1999: 10). Among its merits, Everyday Urbanism has redefined and recalibrated the importance that the traditional notion of public space has taken with respect to the design of the city, carrying on a sort of "rewriting of the public" aimed at giving visibility to a "different social economy" and to a "different space" (Bianchetti 2011). In fact, Everyday Urbanists are skeptical of the "universalist, pessimistic and ambiguous" vision of public space 
that some thinkers, such as Habermas and Sennett, contributed to affirming (Chase et al. 1999: 23). Claiming the impossibility of a clear relationship between public space and democracy, their attention is rather focused on rethinking the concepts of "public" and "place", through the introduction of a new space for reflection that replaces the traditional concept of public space. The so-called "everyday space" is defined as a "connective tissue that binds together all the daily lives, amorphous and so persuasive to be even difficult to perceive" (Chase et al. 1999). In Everyday Urbanists' view, this became a sort of new "public arena" where the debate originates and where forms of participation and claims of citizenship are affirmed (Holston 1999). The patterns of everyday life are the marginal and vacant spaces, filled with further meanings by new populations excluded from social reproduction movements: The homeless, the immigrants, and the new poor, just to name few of them, are affirming new forms of spatial appropriation in those marginal and residual spaces that the contemporary city constantly produces and reproduces in its continuous work of re-signification (Lazzarini 2016).

Worthy to mention the debt that these scholars recognize with respect to the concept of "simultaneity" that Lefebvre has contributed to affirming (Lefebvre 1958; Belli 2013). In fact, the simultaneity can break up the hierarchical and specialized structures of the contemporary city and can lead to juxtapositions, combinations, and collisions of people, places and activities in the everyday spaces. Everyday Urbanists also seem to be close to the distinction between "strategies and tactics" mentioned by Michel De Certeau in his L'invention du Quotidien (De Certeau 1980). In the city of tactics, design and architecture are everywhere and each group or individual is the designer of the city, since it is a space of continuous creation (Chase et al. 1999).

In this view, the everyday space has a crucial role in breaking the preconceived structures of capitalist society. The dissolution of race and class boundaries is accompanied by the emergence of new social possibilities that turn the trivial and marginal in a sort of micro-politics (Chase et al. 1999). This arrangement is accompanied, as we will see later, by the emergence of new forms of citizenship (Holston 1999).

\section{THE “DIFFERENCE” AS ONE OF THE MAIN FEATURES OF THE EVERYDAY SPACE}

If we continue looking at the everyday space following Lefebvre's thought, it comes out another important feature of this space, "the difference". It is by focusing on differences, that the sense of the main theoretical choice of Lefebvre can be perceived, such as the conflicting multiplicity of social practices producing spatial systems and making them socially productive (Belli 2013). It is exactly within this framework that originates the so-called Lefebvre's differential space-time, a dimension which does not exist except in relation with conflicts and oppositions connecting it to other places and times (Lefebvre 1970).

Henri Lefebvre declines the theme of difference especially on the basis of a urban quality that more than others is able to describe the dual nature of the architectural and urban space. The contradictory nature of urban space does not derive from its rational form, but rather stems from its practical and social content, and specifically from its capitalist content (Lefebvre 1972). One of the most important consequences of considering the urban domain a space of contradictions is that it also becomes "political". According to Lefebvre, "The space is not merely a scientific object out of ideology and politics; it has always been political and strategic" (Lefebvre 1972).

The theme of difference in cities, which was discussed by a vast literature in social sciences, was however scarcely explored in urban studies. Today, this would originate stimulating possibilities, especially 
with respect to the heterogeneity resulting from the integration of urban space and virtual space, where communities are moving instantaneously, aiming at transformative practices (Belli 2013).

In the differential urban space, the difference can become a strongly marked contrast. It can lead to conflict, when the occupants of the places are considered. In this complex frame, it seems relevant to consider the positive connotation that the differential space has in opposition to homogeneous-fragmented capitalism space, a space able to affirm the positive and transformative sense of the differences, a space capable of overcoming the opposing resistances. Michel Foucault saw this space as a "device" (Foucault 1984). His interpretation clearly outlines the role it assumes in shaping the integration and the fight for the recognition of the other (Honneth 2002). Bridge and Watson got to affirm that "the differences are built in, and themselves build, the life and spaces of the city" (Bridge and Watson 2003). Understanding the direct correlation between space and differences in relation to the urban domain produces a significant step forward in contemporary conception of public space. This is a space of differences, not only for being a ground of dialogue between different populations, but for simply "being space", therefore for being a field where differences are made and affirmed. This conception of space is also the one taken up by Jane Jacobs and Robert Fincher in their Cities of Difference, work in which the heterogeneity becomes intrinsic feature of the space. In this sense, the emphasis on differences means "taking care of the various ways in which the social and spatial specificity can transform the structures of power and privilege, of the ways in which groups, through a politics of identity and place, can demand, resist, and subvert rights" (Fincher and Jacobs 1998). In other words, connoting the space as a "device" means to understand how the material size of the city can respond to societal changes in the era of migration and globalization. This also means to build a fertile reflection on the opportunity the space has in redefining, not only spatial geographies but also the political and legal systems of our societies.

\section{REDEFINING CITIZENSHIP}

Within the process of subversion of the power and privilege carried on by certain groups in the everyday space, it seems relevant to discuss about the citizenship change as a clear example of the ways in which traditional and established status is subverted by emerging social orders.

Accordingly, we have introduced the nature of differential urban space, its political and social repercussions. These repercussions are able to explain and justify the planning relevance of the undergoing redefinition of some traditional concepts, such as the notion of citizenship (Belli 2013).

Everyday Urbanists, following the thoughts of some scholars such as James Holston, had already talked about a citizenship change. Firstly, they did it by delineating the role that the new urban arena has for democratic action, in the intersection of public, spaces, and identities. They also did it by describing the materialization taking place in some American cities, such as Los Angeles, of new public spaces and activities shaped by lived experience, which "raises complex political question about the meaning of citizenship" (Chase et al. 1999).

Here a premise appears to be necessary. In fact, the conception of citizenship can be interpreted in a static way, as a defined and institutionalized status, or in a dynamic sense, as a social process, set of practices, experiences and activities of citizens actively involved in mutually reshaping rights and responsibilities (Gaeta, Janin Rivolin, and Mazza 2013). If we follow the second conception, which is considered the most relevant by the current debate, some interesting perspectives emerge. According to Etienne Balibar (2012), in modern times, the notions of citizenship and nationality have been progressively identified in 
what can be interpreted as the equivalence of the modern Republican State. This aspect is particularly important especially in the current weakening of the State sovereignty and of the citizens' political community, tending to be reflected in the society both from the cultural and civil point of view. In Balibar's view, national interest and identity are not unity factors of a political community of citizens. It follows that the equation between citizenship and nationality has to be understood as essentially precarious (Balibar 2012).

After having clarified the notional distance between citizenship and State/nationality, the conceptual distance must be also explained on the basis of a second element. Citizenship, unlike the State, is inherently fragile and vulnerable. It has been destroyed and rebuilt several times in a new institutional framework. Recovering again Etienne Balibar's thought, "It has never ceased to oscillate between destruction and reconstruction" (Balibar 2012). The continuous oscillation between formation and decline is responsible during recent times for having transformed citizenship from an a priori concept to a result of contingent conditions that, suddenly, may be lacking in the political and social framework of a community.

James Holston has already described this labile and evanescent connotation of citizenship in the end of the nineties. The American scholar had the merit to critically rethink the concepts of citizenship and political community according to planning, trying to build a substantial dialogue between "planning theory and citizenship changes". According to Holston, the crucial issue to consider during planning is the inclusion of the ethnographic present, that is to say the wide possibilities met in the existing social conditions (Holston 1995). In Holston's thought, however, the key aspect seems to be another one. He stated that the changes continuously lived by citizenship appear to be visible in some sites, in some places at the intersection between "erosion and expansion". The conceptual and critical value of this passage is significant especially considering citizenship not as an established and solid character of a political community, but in relation to its "conflictual" (Balibar 2012), "insurgent" (Holston 1995), therefore purely "urban" (Lefebvre 1972) meaning. In this sense, James Holston stated that the current era is experiencing a progressive change in the conception of citizenship: The distinction between formal and substantive citizenship is useful to suggest how new forms of "insurgent citizenship" are affirming in the contemporary city (Holston 1999). This distinction appears to be crucial in order to grasp a deep difference between two different ways of describing the community membership: on one hand, the so-called "formal citizenship", which refers to belonging to a political community, and on the other one, the "substantive citizenship", concerning the sphere of political, civil, and social rights available to people (Holston 1999).

Holston's theory is an attempt to explain and understand the status of new populations with respect to the traditional national communities. New populations constantly redefine the boundaries of Western societies, making them sort of mobile devices, which continuously change their shape. Introducing multiple forms of citizenship beside the static and unitary conception of political and formal citizenship means to recognize that the societal changes can not just be related to the presence or absence of a formal status, nor to the dominant and ambiguous notion of national identity. It is therefore necessary to interpret the concept of citizenship according to more dynamic and malleable forms, as if it was a real "project and way of life" (Gaeta et al. 2013).

\section{URBAN PLANNING AND CITIZENSHIP}

The drawn profile of the new forms of citizenship characterizing the contemporary city becomes fairly an open theme if we observe it from the view point of the city's physical space and of the ongoing practices 
of territorialisation connoting the thought of the second half of the twentieth century (see: Foucault 1984; De Certeau 1980; Balibar 2012). Relating the new forms of citizenship to the spatiality of the city means to try to understand the consequences produced by the emerging forms of appropriation of urban space carried out by the new populations. This theme, if seen in planning terms, reveals interesting perspectives for understanding the ways in which the urban project has been built in recent years, and allows to measure the changes introduced by the continuous and incessant work of re-definition of citizenship in design practices.

Henri Lefebvre is perhaps the first author to investigate the relationship between urbanism and citizenship. In his view, the role of urban space appears to be relevant in the process of citizenship's construction and reconstruction. The space in Lefebvre has two dimensions: on one hand, it is an empirical arrangement of elements in the landscape; and on the other, it is the place of habitual and spatial practices of social order (Belli 2013). In this framework, the Lefebvre's "right to the city" raises and gives the opportunity to respond to the emerging demands of urban society. It becomes not only the right to take possession of a space for participation in decision-making, but it is also an integral aspect of citizenship (Belli 2013). The purely spatial dimension of citizenship in Lefebvre becomes relevant when he introduces the so-called "right to centrality", that is to say the right of citizens to be present on all networks, on all circuits of communication, information, and exchange (Lefebvre 1972). According to this view, planning has the duty to extend the opportunity to live in the centralities to all citoyens, so that they are not subjected to discriminatory processes and segregation. The centrality in Lefebvre is thus a quality and an essential property of the urban space. It is able to provide the spatial-temporal unit on the basis of which the encounter between the "objects" and the "subject" happens.
According to Luigi Mazza, the relationship between planning and citizenship is purely political (Mazza 2015). The justification lies in the fact that territorial governance practices lead to the (political) redefinition of citizenship. This statement is clearly framed within the context of the capitalist culture, background which gives planning (governo del territorio) the aim of reproducing the capital. Mazza's conclusion is that planning (governo del territorio), understood as a series of political processes that develop and empower the urban and territorial transformations, is a tool of citizenship's redesign (Mazza 2015). In this perspective, the space is the primary resource for setting up any kind of citizenship. Space is the territory in which the institutional and political citizenship is recognized and practiced (Gaeta et al. 2013).

Beside the political connotation of the relationship between planning and citizenship, other scholars have attempted to dissect the ethnographic importance that the redefinition of the new societal borders in relation to the practices of public space's appropriation assumes. In this sense, defining "insurgent" the profile of citizenship means to rethink the social sphere of planning and to describe the realm of possibilities rooted in the experiential diversity of the ethnographic present (Holston 1995). The critical and methodological contribution of urban ethnography turns out to be meaningful since it does not only search process and meaning variations through space, but it creates the useful basis for bringing out the social order embedded in everyday activities. Thanks to the investigation of everyday life tissue, urban ethnography explores, by questioning them, processes and meanings of human actions taking place in the urban space (Herbert 2000). In this view, the planning role intensively dialogues with the continuous processes of expansion and erosion of citizenship mentioned by James Holston. Accordingly, the city's role is purely experiential. It is text and context of the redefinition of social relations. Planning means, 
therefore, seeking antagonist complements based on the possibilities of the ethnographic present and on the insurgent identities and practices disturbing the preconceived social orders (Holston 1995).

\section{CONCLUSIONS}

Within this process of increasing complexity of the citizenship idea, urban planning, and more generally all disciplines dealing with urban space and its continuous expansion (Lazzarini and Mareggi 2015), are at a turning point.

Since planning is facing with the growing complexity of the current urban conditions, it is called to give an answer to questions which are becoming increasingly problematic to ignore, such as: Can urban planning continue to refer its action solely to the formal space of political communities? Or rather should it reformulate its program of intents in order to include among its priorities, the plurality and diversity of social dimensions connoting the spatial marginalization of the city? If we look at the issue from a purely spatial point of view, the question could be rephrased as follows: Can planning keep on ignoring to deal with those residual and interstitial spaces, those spaces connoted by uncertain status, those same spaces which already in the early nineties, Secchi Gregotti had reported as "land to rebuild the project agenda" (Gregotti 1993; Secchi 1994)?

The author's perception is that current planning should necessarily deal with the different nuances of marginality connoting the city. Surprisingly, this has been done just in a small number of experiences. The nuances of marginality which the author is referring to are well expressed by De Certeau's interpretation of marginality, which is a dimension that exceeds the figure of the small groups, embracing the widespread marginalization and cultural activities of the non-producers of culture, which are anonymous, not readable, not symbolized, and gradually becoming "silent majority" (De Certeau 1980). Accordingly, the author's belief is that the present attention of planners should not avoid to look at the ongoing re-signification and re-functionalization of residual spaces, produced as waste during the processes of city's life (Gregotti 1993), as a priority land for the urban project, whereas silent and marginal redefinition of the concept of citizenship silent is undergoing. Just by tackling the project as a research opportunity on the disciplinary domain, as well as a critical description of the existing (Merlini 2001), planning could really deal with that polysemy, changing in time and space, that spatial fragility and vulnerability between the warp of woven strands of the urban fabric texture (Lefebvre 1958; Lazzarini 2011) ${ }^{5}$.

Urban planners are therefore called to choose, quoting De Certeau, between a "strategic" or a "tactical" mode of action. In this choice, "strategy" stands for a calculation of power relationships that becomes possible from the time in which an individual of will and power can be isolated in a given "environment", in a place that can be circumscribed as "his/her own place" according to a political, economic, or scientific rationality. "Tactical", on the contrary, means a mode of action that creeps in a piecemeal place without grasping it in its entirety, playing with the events to transform them in "opportunities", depending largely on the design of the contextual circumstances (De Certeau 1980). The author's belief is that perhaps the tactical course of action, which is free, open to the ethnographic present (Holston 1999), oriented to incorporate the elusive elements of the city (Chase et al. 1999), could be able to better grasp the new social configurations of urban reality. Accordingly, the cacophony, the ephemerality, and the simultaneity of urban spaces could constitute the relevant dimension of contemporary urbanism.

\section{Notes}

1. See, for example: Di Cori, P. and C. Pontecorvo, eds. 2007. Tra Ordinario e Straordinario: Modernità e Vita Quotidiana. Roma: Carocci. This work was developed as 
the first result of a series of meetings held at the Faculty of Psychology 2, University La Sapienza in Rome between February and April 2005. In the same years, a comparative research of Italian, Swedish, and North American families, sponsored by the Sloan Center on everyday lives of families, entitled "Everyday Lives of Working Families: Italy, Sweden and the United States" had the purpose to describe and understand how the family organizes and carries out daily activities.

2. This theme was deeply explored by Michel Foucault in his "Des Espace Autres" (in Architecture, Mouvement, Continuitè no. 5 , October 1984).

3. See Kelbaugh (2001) and Chase, Crawford, and Kalisky (1999).

4. "Everyday urbanism in nonutopian because it celebrates and builds the everyday, ordinary life and reality, with little pretense about the possibility of a perfectible, tidy or ideal built environment. (...) It is conversational in its openness to populist informality. It is non-structuralist because it downplays the direct relationship between physical design and social behaviour." (Kelbaugh 2001).

5. A recent research embracing partially the issues to which the author is referring to is "Recycle Italy" (2012-2015), a project of national interest (PRIN). "Aim of the project is the exploration and the development of new cycles of life for those spaces, those elements, those passages of the city and the territory that have lost their sense, use and care. (...) The research aims to explore the operational impacts of the recycling process on the urban system and the traces of urbanization that affect the territory so that these 'materials' will return to be a part, together with the environmental system, of a unique metabolism" (http://www.recycleitaly. it).

\section{References}

Balibar, E. 2012. Cittadinanza (Citizenship). Torino: Bollati Boringhieri.

Basilico, G. and S. Boeri. 1998. Sezioni del Paesaggio Italiano (Section of Italian Landscape). Udine: Arte.

Belli, A. 2013. Spazio, Differenza e Ospitalità. La Città Oltre Henry Lefebvre (Space, Difference and Hospitality. The City Beyond Henry Lefebvre). Roma: Carocci.

Bianchetti, C. 2003. Abitare la Città Contemporanea (Inhabiting the Contemporary City). Milano: Skira Editore.

—. 2011. Il Novecento è Davvero Finito. Considerazioni Sull'urbanistica (The Twentieth Century Is Really Over. Consideration on Urban Planning). Roma: Donzelli.

—. 2015. "Individui, Scenari Molecolari, Piccolo Cerchie" (Individuals, Molecular Scenarios, Small Circles). In La
Città del XXI Secolo. Ragionando con Bernardo Secchi (The XXI Century City. Reasoning With Bernrdo Secchi), edited by A. Becchi, C. Bianchetti, P. Ceccarelli, and F. Indovina. Milano: Angeli.

Boeri, S., A. Lanzani, and E. Marini. 1993. Il Territorio che Cambia (The Changing Territory). Milano: Segesta.

Bourdin, A. 2005. La Métropole des Individus (The Metropolis of Individuals). La Tourd'Aigues: Edition de l'Aube.

Bridge, G. and S. Watson, eds. 2003. "City Differences." In $A$ Companion to the City, edited by G. Bridge and S. Watson. Malden-Oxford-Carlton: Blackwell.

Chase, J., M. Crawford, and J. Kalisky, eds. 1999. Everyday Urbanism. New York: The Monacelli Press.

De Certeau, M. 1980. L'invention du Quotidien. Arts de Faire (The Practice of Everyday Life). Paris: Gallimard.

Di Cori, P. and C. Pontecorvo, eds. 2007. Tra Ordinario e Straordinario: Modernità e Vita Quotidiana (Between Ordinary and Extraordinary: Modernity and Everyday Life). Roma: Carocci.

Fincher, R. and J. M. Jacobs. 1998. Cities of Difference. New York/London: The Guilford Press.

Foucault, M. 1984. "Des Espaces Autres" (Of Other Spaces: Utopias and Heterotopias). Architecture, Mouvement, Continuité 5:46-49.

Gaeta, L., U. Janin Rivolin, and L. Mazza. 2013. Governo del Territorio e Pianificazione Spaziale (Territorial Government and Spatial Planning). Milano: CittàStudi Edizioni.

Gregotti, V. 1993. "Il Disegno Degli Spazi Aperti" (The Design of Open Spaces). Casabella (597-598):2-3.

Herbert, S. 2000. "For Ethnography." Progress in Human Geography 24(4):550-568.

Holston, J. 1995. "Spaces of Insurgent Citizenship." Planning Theory 13:35-52.

— ed. 1999. Cities and Citizenship. Durham: Duke University Press.

Honneth, A. 2002. Lotta per il Riconoscimento. Proposte per Un'etica del Conflitto (Fight for the Recognition. Proposals for an Ethics of Conflict). Milano: Il Saggiatore.

Infussi, F. and C. Merlini. 1998. "Modi e Consuetudini di Costruzione Della Città. Note per un Atlante Degli Ambienti Urbani di Seveso" (Ways and Practices of City Construction. Notes for an Atlas of Seveso Urban Spaces). Comune di Seveso (Municipality of Seveso).

Kelbaugh, D. 2001. "Three Urbanism and the Public Realm." Presented at the 3rd International Space Syntax Symposium, Atlanta.

Lazzarini, A. 2011. Polis in Fabula. Metamorfosi Della Città Contemporanea (Polis in Fabula. Methamorphosis of the Contemporary City). Palermo: Sellerio Editore.

Lazzarini, L. 2016. "Redefining the Domestic Between New 
Forms of Dwelling and Emerging Social Problems." MONU \#24 Domestic Urbanism.

Lazzarini, L. and M. Mareggi. 2015. "Progettare lo Spazio Urbano Dilatato" (Designing the Expanded Urban Space). Urbanistica Informazioni 263:73-76.

Lefebvre, H. 1958. Critique de la vie Quotidienne (The Critics of Everyday Life). Paris: 1'Arche.

- 1970. La Révolution Urbaine (The Urban Revolution). Paris: Gallimard.

- 1972. Espace et Politique (Space and Politics). Paris: Éditions Anthropolis.

Mareggi, M. 2011. Ritmi Urbani (Urban Rhythms). Rimini: Maggioli.

—. 2014. "Forme e Gestione Degli Spazi Della Vita in Pubblico" (Forms and Management of Spaces of Public Life). Urbanistica Informazioni 257:114-117.

Mazza, L. 2015. Spazio e Cittadinanza. Politica e Governo del Territorio (Space and Citizenship. Territorial Policies and Government). Roma: Donzelli Editore.

Merlini, C. 2001. "Sulla Densità" (On Density). PROCAM, facoltà di Ascoli Piceno, Università degli Studi di Camerino.

Merlini, C. 2009. Cose/Viste. Letture di Territori (Things/Views. Reading Territories). Sant'Arcangelo di Romagna: Maggioli.

Munarin, S. and M. C. Tosi. 2001. Tracce di Città (City Traces). Milano: Angeli.

Secchi, B. 1984. "Le Condizioni Sono Cambiate" (Conditions Have Changed). Casabella (498-499):8-13.

. 1989. Un Progetto per L'urbanistica (A Project for
Urban Planning). Torino: Einaudi.

. 1994. "Resoconto di una Ricerca" (Report of a Research). Urbanistica 103:25-30.

. 1995. "Dell'utilità di Descrivere ciò che si Vede, si Ascolta, si Tocca" (On the Utility to Describe What Is Seen, Listened, Tauched). Relazione al Convegno Internazionale di Prato (Report of the International Congress in Prato).

—. 2000. Prima Lezione di Urbanistica (First Lecture of Urban Planning). Bari: Laterza.

- 2005. La Città del Ventesimo Secolo (The City of the XX Century). Bari: Laterza.

- 2013. La Città dei Ricchi e la Città dei Poveri (The City of Rich and the City of Poor). Bari: Laterza.

Vaccaro, S. 2011. Michel Foucault. Spazi Altri. I Luoghi Delle Eterotopie (Michel Foucault. Other Spaces. The Places of Heterotopias). Milano: Mimesis Edizioni.

Viganò, P. 2000. La Città Elementare (The Elementary City). Milano: Skira.

Wirth, L. 1938. "Urbanism as a Way of Life." The American Journal of Sociology 44(1):1-14.

\section{Bio}

Luca Lazzarini, Ph.D. candidate in Urban and Regional Development (XXXI cycle), Interuniversity Department of Urban and Regional Studies and Planning (DIST), Politecnico di Torino, Italy; research fields: urban and territorial project, inter-institutional cooperation, inter-municipality, governace, urban and periurban agriculture. 